\title{
Evaluation of a Psychoeducational Intervention in the Development of Social and Communication Skills for Incoming Medical Students at a Bilingual University
}

\author{
Robson Zazula*, 1 \\ Orcid.org/0000-0001-8473-050X \\ Simone Appenzeller ${ }^{2}$ \\ Orcid.org/0000-0001-5075-4474
}

${ }^{1}$ Universidade Federal da Integração Latino Americana (UNILA), Foz do Iguaçu, PR, Brasil

${ }^{2}$ Universidade Estadual de Campinas, Campinas, SP, Brasil

\begin{abstract}
Concerns about social skills in academic and professional settings are rarely considered. Undergraduate students and professionals without social and communication skills lead to an increase in the incidence of malpractice claims and interpersonal conflicts. The study is aimed at evaluating a psychoeducational intervention focused on improving social skills for incoming medical students at a bilingual university. A psychoeducational intervention was conducted in a required course from first academic term with 57 incoming medical students from Brazil and other Latin America Countries whose average age was 21.28 $(S D=4.04)$. The psychoeducational intervention occurred fortnightly for seven sessions which aimed to develop theoretical knowledge about communication and interpersonal relationships in academic and professional settings, interpersonal patterns, teamwork, and interpersonal problem solving. Prior and after the intervention, the students answered two self-report instruments to identify social skills and their academic experience. After the intervention, there was a significant average increase in scores related to social skills and academic experience. These increases were evident in the dimension/factor scores, as well as the total scores. The results demonstrated the importance of early and short-term interventions as a way to develop social and communication skills.
\end{abstract}

Keywords: Communication, interpersonal skills, social skills, psychoeducational intervention.

* Mailing address: Universidade Federal da Integração Latino Americana (UNILA), Instituto Latino-Americano de Ciências da Vida e da Natureza, Curso de Medicina, Avenida Tarquinio Joslin dos Santos, 1000, Sala G203, Foz do Iguaçu - PR, Brazil 85870-90. Phone: +55(45)35292763 / +55(45)999771175. E-mail: robsonzazula@ gmail.com

O presente estudo é parte de um projeto de inovação educacional envolvendo aspectos da psicologia e da educação, desenvolvido pelo primeiro autor sob orientação da segunda autora, durante o programa de especialização em Educação para Profissionais de Saúde, promovido pelo Instituto FAIMER-Brasil, em parceria com a Universidade Federal do Ceará (UFC), apoio da Secretaria de Gestão do Trabalho e da Educação na Saúde (SGTES), secretaria do Ministério da saúde e patrocínio da Foundation for Advancement of International Medical Education and Research (FAIMER), organização sem fins lucrativos da Educational Commission for Foreign Medical Graduates (ECFMG). Os autores agradecem a UNILA e ao Instituto Regional FAIMER-Brasil pelo apoio técnico e acadêmico durante o programa de educação psicoeducacional. Todos os autores participaram da análise dos dados e revisão, aprovando a versão final do manuscrito. 


\section{Avaliação de uma Intervenção Psicoeducacional para o Desenvolvimento de Habilidades Sociais e Comunicação em Ingressantes de Medicina em uma Universidade Bilíngue}

\section{Resumo}

A preocupação com o desenvolvimento de habilidades sociais no contexto acadêmico e profissional não é algo frequente. Acadêmicos e profissionais sem habilidades sociais tendem a apresentar elevadas frequências de conflitos interpessoais e negligência na realização de tarefas. $\mathrm{O}$ objetivo do presente estudo foi avaliar uma intervenção psicoeducacional focada no desenvolvimento de habilidades sociais em acadêmicos ingressantes do curso de medicina em uma instituição de ensino superior bilíngue. A intervenção psicoeducacional foi realizada em uma disciplina obrigatória do primeiro período, com a participação de 57 acadêmicos do Brasil e de outros países da América Latina. A idade média dos estudantes era 21,28 anos $(D P=4,04)$. A intervenção foi realizada durante sete sessões com frequência quinzenal, cujos objetivos envolveram o conhecimento teórico sobre a comunicação e o relacionamento interpessoal no contexto profissional e acadêmico, padrões de relacionamento interpessoal, trabalho em equipe e resolução de conflitos interpessoais. Antes e após a intervenção os estudantes responderam a instrumentos para avaliar o repertório de habilidades sociais e interpessoais e as vivências acadêmicas. Após a intervenção, foi identificado aumento significativo nos escores médios totais em relação a habilidades sociais, comunicação e vivências acadêmicas. $\mathrm{O}$ estudo demonstrou a importância de intervenções curtas e precoces como meio de desenvolver habilidades sociais e de comunicação.

Palavras-chave: Comunicação, relacionamento interpessoal, habilidades sociais, intervenção psicoeducacional.

\section{Evaluación de una Intervención Psicoeducativa para el Desarrollo de Habilidades Sociales y de Comunicación Estudiantes que Ingresan a Carrera de Medicina en una Universidad Bilingüe}

\section{Resumen}

La preocupación con las habilidades sociales en los contextos profesional y académico no es algo frecuente. Estudiantes de pregrado y profesionales con pocas habilidades sociales tienen mayor probabilidad de conflictos interpersonales y problemas en la ejecución de tareas. El objetivo del presente estudio fue evaluar una intervención psicoeducativa con foco en el desarrollo de las habilidades sociales en estudiantes que ingresan a carera de medicina en una universidad bilingüe. La intervención psicoeducativa fue conducida en una disciplina obligatoria en el primer período académico. Participaron 57 estudiantes de Brasil y otros países de América Latina. La edad media de los estudiantes fue 21,28 años $(D E=4.04)$. La intervención fue conducida durante siete sesiones con frecuencia quincenal que objetivaron desarrollar el conocimiento teórico sobre comunicación y relacionamiento interpersonal en el contexto profesional y académico, patrones de relaciones interpersonal, trabajo en equipo, y resolución de conflictos interpersonales. Antes y después de la intervención los estudiantes respondieron instrumentos para evaluar el repertorio de habilidades sociales y vivencias académicas. Al fin de la intervención fue identificado un crecimiento significativo en los puntajes medios en relación con las habilidades sociales, comunicación y vivencias académicas. Los resultados del estudio demuestran la importancia de las intervenciones cortas y tempranas como un medio para el desarrollo de habilidades sociales y comunicativas.

Palabras clave: Comunicación, relaciones interpersonales, habilidades sociales, intervención psicoeducativas. 
One of the main challenges of new incoming students is the adaptation. The first academic term is a critic period which requires intense integration, adaptation, and development of new competences for all students. This is more important in universities with a large number of incoming international students. These students will have additional challenges in comparison with national students. Not only will they have to adapt to the university, but they will also have to adapt to a new country and to a different culture (Mesidor \& Sly, 2016; Tavakoli, Lumley, Hijazi, Slavin-Spenny, \& Parris, 2009; TerrazasCarrillo, Hong, \& Pace, 2014). The impact of first academic experiences may vary according to each university, but it is always dependent on the students' academic and social level of integration during their introduction (Pascarella \& Terenzini, 1991).

The most important goal for all universities should be to, not only provide knowledge to students, but encourage them to develop social, academic and professional skills, which will increase academic or professional purposes for all students. In other words, new students need to use different competences during their academic life, such as communication, social, interpersonal, and academic skills, as they will be useful in improving relationships with classmates, faculties, patients and other professionals (Biggs, Agger, Dent, Allery, \& Coles, 1994; Sorinola, 2014).

When we discuss undergraduate medical students, we cannot forget the importance of social skills (Zick, Granieri, \& Makoul, 2007). In addition, these skills are an important part of emotional intelligence and could help future physicians in professional and personal situations (Grewal, 2008; Johnson, 2015; Satterfield \& Hughes, 2007; Wagner, Moseley, Grant, Gore, \& Owens, 2002). Moreover, communication is a central part of every interpersonal interaction in a healthcare setting (Deveugele, 2015). Currently, different medical schools are changing their curriculum in terms of structure, methods and strategies to provide a better skill learning process in the areas of communication and social skills (Al Odhayani \& Ratnapalan, 2011). However, the teaching of this group of skills is frequently neglected and rarely integrated into the curriculum and, most of time, these skills are not included during assessment situations or contextualized to practical activities during undergraduate medical school settings (Denniston, Molloy, Nestel, Woodward-Kron, \& Keating, 2017; Deveugele, 2015; Pureza, Rusch, Wagner, \& Oliveira, 2012).

Furthermore, academic and professional competences are directly related to social and communication skills. There are different definitions and concepts about social skills and their main role in psychology. For instance, social skills could be defined as a behavior forwarded to social competence which could enable the person to communicate and live with others in society (Caballo, 2007; Del-Prette \& Del-Prette, 2013, 2016; McCallin \& Bamford, 2007) despite cultural variables (Argyle, Furnham, \& Graham, 1980). In other words, social skills can contribute to positive interpersonal relationships, which then lead to better health, personal satisfaction, professional accomplishment, better teamwork, life of quality, and respect to others (Del-Prette \& Del-Prette, 2016).

Despite the benefits, the importance of social skills in academic and professional settings is rarely considered. Undergraduate students and professionals without social and communication skills lead to an increase in the incidence of malpractice claims and interpersonal conflicts. Moreover, social skills are deeply related to empathy in any setting (Benbassat \& Baumal, 2005; Gysels, Richardson, \& Higginson, 2004; Wagner et al., 2002). For that reason, social skills training is important for all undergraduate students, especially to undergraduate medical students and future physicians.

Given these premises, we designed a psychoeducational intervention, which focused on the development of social skills for incoming medical students in a bilingual university. For the present study, psychoeducational intervention was defined as any structured educational activity which was aimed to 
increase theoretical knowledge and behaviors related to social skills in professional and interpersonal settings as well as academic experiences. In this study, the following aims were taken into consideration: (a) to improve socials skills in academic and interpersonal settings and (b) to increase the probability of effective adaptation to university, for incoming medical students at university. We hypothesized that the development of social skills, understood as a broader range of behaviors such as communication, assertiveness and expression of feelings (Del-Prette \& Del-Prette, 2013), could be a first step for the training of other necessary behaviors and skills, such as breaking bad news, empathy, counseling and communication with patients in real settings. To achieve theses aims, we acknowledged that the most important element of the psychoeducational intervention was the communication and interpersonal relationship between medical students, fellows and classmates during the first academic term of undergraduate medical school.

\section{Method}

\section{Study Design and Participants}

We completed a pre- and post-evaluation study of a psychoeducational intervention and all data was collected in 2017 at the beginning and ending of the first academic term (from March 2017 to June 2017). All incoming students from $2017(\mathrm{n}=57)$ were from Universidade Federal da Integração Latino Americana (UNILA), a Brazilian public and bilingual university located in Foz do Iguaçu, Brazil, where Portuguese and Spanish were spoken by students, who were from all over Latin America. The present study had students from Brazil and another 12 Latin American countries (i.e., Argentina, Bolivia, Chile, Paraguay, Peru, Ecuador, Colombia, Venezuela, Dominican Republic, Cuba, Guatemala, and Mexico). The study was approved by the Brazilian Ethics Committee (CAAE 68528217.5.0000.5231) and all students signed the informed consent form prior to their participation.

\section{Instruments}

Sociodemographic questionnaire is a 5-item instrument containing the following: age, sex, and nationality.

Social Skills Inventory (SSI-Del-Prette) is a Brazilian 38-item self-report instrument to assess social and interpersonal skills and characterize social skills deficits and resources in different contexts. SSI-Del-Prette is divided in five factors, as follow: $(F 1)$ self-affirmation and coping with risk, (F2) self-affirmation in the expression of positive feelings, $(F 3)$ conversation and social ease, $(F 4)$ self-exposure to unknown people and new situations and, $(F 5)$ self-control of aggressiveness. Each item must be answered with a five-point Likert scale (from zero to four), ranging from never or rarely (for every ten situations, the reaction needs to be two times at most and thus rated a zero) to always or almost always (for every ten situations, the reaction is nine or ten times and thus rated a four). The Portuguese version was validated for the Brazilian population (Del-Prette \& Del-Prette, 2016) and the Spanish version was translated and adapted for Spanish-speakers (Olaz, Medrano, Greco, \& Del Prette, 2009). According to Olaz et al. (2009), the Spanish version of SSI-Del-Prette is equivalent in its items and factors to the original version (DelPrette \& Del-Prette, 2016) and both versions demonstrate adequate reliability, validity and high values of internal consistency. Cronbach's Alpha for Brazilian Portuguese was 0.79 ( $F 1$ : $\alpha=0.96 ; F 2: \alpha=0.86 ; F 3: \alpha=0.81 ; F 4: \alpha=0.75$; $F 5: \alpha=0.74)$ while for Spanish version was 0.75 $(F 1: \alpha=0.66 ; F 2: \alpha=0.70 ; F 3: \alpha=0.60 ; F 4: \alpha=$ $0.52 ; F 5: \alpha=0.64)$.

Academic Experiences Questionnaire - reduced version (AEQ-r) is a 60-item self-report instrument to depict the academic experience in five dimensions, as follow as (a) personal, related to physical and psychologic welfare, emotional balance, affective stability, optimism, self-confidence and problem solving; (b) interpersonal, related to relationships with colleagues and intimacy social situations and looking to others for help in critical or difficult 
situations; (c) career, related to feelings, emotions, and knowledge about competences and skills required from the students during whole curricula; (d) learning, related to study habits and time management of students, including study routines, the use of learning resources and strategies and the preparation for evaluations; (e) institutional, associated with opinions, knowledge and, expectations about the education institution. Each item must be answered with a five-point Likert scale, ranging from one (not important to me) to five (very important to me), according to experiences in academic life. AEQ-r was adapted to Portuguese (Brazil) by Granado, Santos, Almeida, Soares, and Guisande (2005) and the version translated and adapted to Spanish by Rodríguez, Urazán, and Arango (2009). Both versions demonstrate adequate reliability and validity and values of internal consistency up to 0.60 . The Brazilian version presented internal consistency as follows: personal $(\alpha=0.80)$, interpersonal $(\alpha=$ $0.82)$, career $(\alpha=0.86)$, learning $(\alpha=0.78)$ and institutional ( $\alpha=0.77$; Granado et al., 2005) while the Spanish version presented personal ( $\alpha=0.88)$, interpersonal $(\alpha=0.82)$, career $(\alpha=$ $0.77)$, learning $(\alpha=0.81)$ and institutional $(\alpha=$ 0.65; Rodríguez et al., 2009).

\section{Data Collection}

The first contact between the researcher and the students occurred in the first meeting among lecturers and students, during which they were invited to be part of the study. The recruitment consisted of verbal invitations during this first meeting as well as during the first class of the required course of academic term at medical school coordinated by the principal investigator. The inclusion criteria were: (a) be a regular medical student from the first academic term and (b) accept to be part of the study.

Before and after the intervention, quantitative methods were used to enhance the understanding of the results, such as the sociodemographic questionnaire and standardized outcomes measures for social and interpersonal skills (SSIDel-Prette), and academic experience (AEQ-r). The pre-intervention assessment occurred on the day before the first class and the post-test occurred a week after the end of intervention.

\section{Structure of the Psychoeducational Intervention}

The proposed intervention was part of the required course in first academic term at medical school. There was no previous training in communication or interpersonal skills. The overall aim of the intervention was to develop communication, social and interpersonal skills to improve relationships and socialization in academic and professional settings. The intervention was conducted in large groups of up to 20 students and lasted 14 weeks, with one session each fortnight (seven sessions in total). Each session lasted four hours and was designed with active learning strategies and involves the following activities and objectives:

1. General definitions about communication. Students were instructed to worked in small groups of up to five to define the concept of communication and describe the importance of communication in interpersonal relationships. The session aimed to discuss the role of interpersonal and communication skills in academic and healthcare settings from a generic perspective.

2. Interpersonal skills in healthcare practice. Students were required to work in small groups of up to five to rehearsal physician-patient situations and develop communication and interpersonal skills. During the activity, some students were required to interview a simulated patient (i.e., played by another student) while the rest of them observed and registered the main topics of the simulated situation. The session aimed to show the difference between the personal and professional characteristics of the physician during a medical care situation.

3. Assertive, aggressive, and passive communication patterns. The session had two parts: the first one was a traditional class about different communication and interpersonal patterns for all students, and the second one was a role-play in groups 
of up to five. During the second part, some students depicted patients while other students acted as an interviewer. Students with no designated roles were instructed to observe and evaluate the situation in terms of communication, interpersonal and social skills patterns and provide verbal feedback to the student who was leading the interview. The session aimed to identify and analyze different communication and interpersonal patterns in simulated situations.

4. Group and teamwork. The session had two parts: in the first part students had to work in small groups of up to five or six and create a dramatization related to the main theme of the session in a healthcare setting. This activity aimed to define and exemplify group and team work as well as the differences and similarities among them. After this first activity students were requested to sit in a circle and were instructed to solve a challenge which aimed to create a real situation which required teamwork. This second activity required all the students to work together in one group.

5. Conflicts. Students worked in groups of up to five to create a conflict situation in a healthcare setting, such as a physicianpatient conflict. Each group presented the conflict situation to the other three groups of students and, at the end of this rotation activity, all students had to discuss and present the most important strategies to manage and solve interpersonal conflicts. The session aimed to define conflict and describe strategies to manage and solve them. An additional objective was to create and opportunity for all students to experience and train in communication, social and interpersonal skills using simulated situations similar to professional settings.

6. Physician-patient relationship. Students worked in three groups of up to six and discussed different situations involving physician-patient relationships. After this activity a rotation system was adopted, and one student from each group went to another group of students to present the main results of the previous discussion in his group. The session aimed to discuss the physician-patient relationship and the role of interpersonal skills in the daily work of a physician.

7. Feedback. This was the last session and was divided in two parts: the first one was an expositive class about the definitions, main types and the importance of feedback in personal and professional relationships. The second one used an active learning technique to promote and increase the use of verbal feedback among students, who worked together in one group (of up to 20 people) and were instructed to give written feedback to their peers that expressed experiences, feelings, concerns, emotions, and ideas about the psychoeducational process and experiences in groups.

\section{Statistical Analysis}

The characterization of the students was based in sociodemographic characteristics collected prior to intervention, such as gender, age and nationality, and were reviewed by exploratory analysis. All students from this study were split into groups based in their nationality and gender; and group analysis was performed with chi-square tests.

Data from pre- and post-intervention was collected using SSI-Del-Prette and AEQ-r. Both instruments were scored according to the instrument guidelines which included a general score and scores corresponding to the factors or dimensions for each instrument (all described above). Additionally, general and factorial scores of SSI-Del-Prette were encoded into percentiles and distinguished between gender, according to a norm referenced table.

Data from both instruments was summarized using frequencies, means and standard deviations according to the level of variance. For pre- and post-intervention comparisons, a paired $t$-test for continuous variables was used when the assumptions were attended (i.e., differences between pre- and post-intervention data followed normal distribution such as F2, F3, 
F4 factors and total score of SSI-Del-Prette, and interpersonal, learning, institutional dimensions and AEQ-r total score), and Wilcoxon MatchedPairs Test was used when the assumptions were not attended (i.e., differences between pre- and post-intervention data did not follow normal distribution such as F1 and F5 factors of SSIDel-Prette and the career dimension of AEQ-r). Standardized Effect Size were also calculated for all factors/ dimensions as well as general scores for both scales using $d$ 'Cohen. Results were defined as statistically significant with $p<$ .05 or highly significant with $p<.01$. Statistical analyses were performed in SPSS (version 23; IBM, 2015).

Additionally, the reliability of changes after the intervention were assessed based on Jacobson and Truax (1991). The Reliable Change Index (RCI) was calculated, which was used to determine if the changes between preand post- intervention identified for each student or the group resulted from the intervention or due measurement errors. The same method to calculate the standard error of measure $\left(\mathrm{S}_{\mathrm{E}}\right)$ and the standard error of the difference $\left(\mathrm{S}_{\text {diff }}\right)$ were used in the present study, and a scatter plot was created for pre- and post-intervention scores for SSI-Del-Prette and AEQ-r with jagged band to show the RCI for all students in the intervention. All points falling inside the shaded area around the diagonal represent no statistically reliable change; and all points outside the shaded area represent changes that were statistically reliable. Points above the shaded area represent an improvement; and points below the shaded area represent no change or deterioration.

\section{Results}

Sociodemographic variables were obtained from the sociodemographic questionnaire. Of all students from first term at medical school, $27(47.36 \%)$ were male and $30(52.63 \%)$ were female. When we analyzed the nationality, we identified 33 students (57.89\%) from Brazil and 24 students (41.1\%) from other Latin America countries (non-Brazilian). According to the country of origin, we had five students from Paraguay and Peru (8.77\% of each), four from Chile (7.01\%), two from Argentina and Colombia (3.51\% each one), and one student $(1.75 \%)$ from each of these countries: Ecuador, Venezuela, Dominican Republic, Mexico, Guatemala and Cuba. There were no significant differences in gender $(p=.701)$ when compared in groups by nationality (Brazilian and nonBrazilian). The average age of all students was $21.28 \pm 4.04$ years. For Brazilians students the average age was $21.75 \pm 4.86$ years, and for nonBrazilian students the average age was $20.69 \pm$ 2.5 years. There were no significant differences in age between Brazilian and non-Brazilian students $(p=.626)$ and gender $(p=.729)$.

In the SSI-Del-Prette, F1, which is related to interpersonal situations that demand assertion and defense of rights, increased significantly after the intervention $(p<.05 ; \mathrm{z}=-2.814)$ as well as F3 $(p<.05 ; t=-2.95)$, which is related to conversation and social interaction. There were no differences between pre- and postintervention for F2, F4 and F5. The SSI-DelPrette Total Score increased significantly in post-intervention. The standardized ES (effect size) were from -0.1410 to -0.3907 in all factors and the standardized ES of the SSI-Del-Prette total score was -0.3484 (see Table 1).

In the AEQ-r, the dimension related to interpersonal $(p>.05 ; \mathrm{z}=-3.13)$, career $(p$ $>.05 ; \mathrm{z}=-2.904)$ and institutional $(p>.05$; $\mathrm{z}=-2.319)$ issues increased significantly in post- intervention assessment. The AEQ-r total score increased significantly after the end of intervention $(p>.01 ; z=-3.255)$. The standardized ES were from -0.22 to -0.4145 in all dimensions and the standardized ES of the AEQ-r total score was - 0.4311 (see Table 2).

The RCIon the SSI-Del-Prette total score was 42.48, $\mathrm{S}_{\mathrm{E}}$ was 15.33 and $\mathrm{S}_{\text {diff }}$ was 21.67. Among all participants, $29(50.87 \%)$ students showed a statistically significant positive reliable change and $16(28.07 \%)$ students showed a statistically significant negative reliable change. Results preand post-intervention without reliable change were found for 12 students. Within these students, 3 (5.26\% of all participants) students showed a negative change without reliable change and 9 
Table 1

Comparison of SSI-Del-Prette Pre- and Post- Intervention for all Incoming Medical Students from First Academic Term

\begin{tabular}{|c|c|c|c|c|}
\hline Factors & $\begin{array}{l}\text { Pre- Intervention; } \\
\text { Mean }(S D)\end{array}$ & $\begin{array}{l}\text { Post- Intervention; } \\
\text { Mean }(S D)\end{array}$ & $\begin{array}{c}\text { Standardized } \\
\text { ES }\end{array}$ & $\begin{array}{l}\text { Test statistic } \\
\text { and } p \text {-value }\end{array}$ \\
\hline $\mathrm{F} 1$ & $62.26(25.87)$ & $68.8(22.71)$ & -0.2635 & $\begin{array}{l}z=-2.814 \\
p=.005^{* *}\end{array}$ \\
\hline $\mathrm{F} 2$ & $58.49(26.34)$ & $62.11(24.4)$ & -0.1872 & $\begin{array}{c}t=-1.414 \\
p=.163\end{array}$ \\
\hline F3 & $61.83(33.77)$ & $71.83(25.81)$ & -0.3907 & $\begin{array}{c}t=-2.95 \\
p=.005^{* *}\end{array}$ \\
\hline $\mathrm{F} 4$ & $68.61(25.78)$ & $72.98(22.72)$ & -0.1509 & $\begin{array}{c}t=-1.612 \\
p=.107\end{array}$ \\
\hline F5 & $52.67(25.29)$ & $55.96(24.81)$ & -0.1410 & $\begin{array}{c}z=-1.065 \\
p=.291\end{array}$ \\
\hline Total Score & $64.25(30.65)$ & $71.58(26.41)$ & -0.3484 & $\begin{array}{l}t=-2.631 \\
p=.011^{*}\end{array}$ \\
\hline
\end{tabular}

Note. $S D=$ Standard Deviation; $E S=$ Effect Size; F1 = Self-affirmation and Coping with risk; F2 = Self-affirmation in the expression of positive feelings; F3 = Conversation and social ease; F4 = Self-exposure to unknown people; F5 = Self-control of aggressiveness.

$* p<.05 ; * * p<.01$

Table 2

Comparison of AEQ-r Pre- and Post- Intervention for all Incoming Medical Students from First Academic Term

\begin{tabular}{|c|c|c|c|c|}
\hline Dimensions & $\begin{array}{l}\text { Pre-intervention; } \\
\text { Mean }(S D)\end{array}$ & $\begin{array}{l}\text { Post-intervention; } \\
\text { Mean }(S D)\end{array}$ & $\begin{array}{c}\text { Standardized } \\
\text { ES }\end{array}$ & $\begin{array}{l}\text { Test statistic } \\
\text { and } p \text {-value }\end{array}$ \\
\hline Personal & $2.582(0.672)$ & $2.531(0.728)$ & -0.0657 & $\begin{array}{c}z=-0.702 \\
p=.483\end{array}$ \\
\hline Interpersonal & $3.424(0.484)$ & $3.616(0.399)$ & -0.4145 & $\begin{array}{c}t=-3.13 \\
p=.003 * *\end{array}$ \\
\hline Career & $3.936(0.386)$ & $4.071(0.345)$ & -0.2719 & $\begin{array}{l}z=-2.904 \\
p=.004 * *\end{array}$ \\
\hline Learning & $3.512(0.350)$ & $3.59(0.378)$ & -0.3071 & $\begin{array}{c}t=-1.661 \\
p=.102\end{array}$ \\
\hline Institutional & $3.553(0.331)$ & $3.671(0.366)$ & -0.2200 & $\begin{array}{l}t=-2.319 \\
p=.024^{*}\end{array}$ \\
\hline $\begin{array}{l}\text { AEQ-r Total } \\
\text { Score }\end{array}$ & $3.372(0.241)$ & $3.475(0.252)$ & -0.4311 & $\begin{array}{l}t=-3.255 \\
p=.002 * *\end{array}$ \\
\hline
\end{tabular}

Note. $S D=$ Standard Deviation; ES = Effect Size.

$* p<.05 ; * * p<.01$

(15.79\% of all participants) students showed a positive change without reliable change.

The RCI on the AEQ-r total score was $0.23, \mathrm{~S}_{\mathrm{E}}$ was 0.08 and $\mathrm{S}_{\text {diff }}$ was 0.13 . Among all participants, 28 students $(49.12 \%)$ showed a statistically significant positive reliable change and 11 students (19.29\%) showed a statistically significant negative reliable change on AEQ-r. Results pre- and post-intervention without reliable change were found for 18 
students. Within these students without RCI, 9 (15.79\% from all participants) students showed a negative change while $9(15.79 \%$ from all participants) students showed a positive change. Figure 1 shows the scatter plot for pre- and post-intervention scores for SSI-Del-Prette and AEQ-r with jagged band to show reliable change for all participants during the intervention, which were split into two different groups: Brazilian and non-Brazilian.
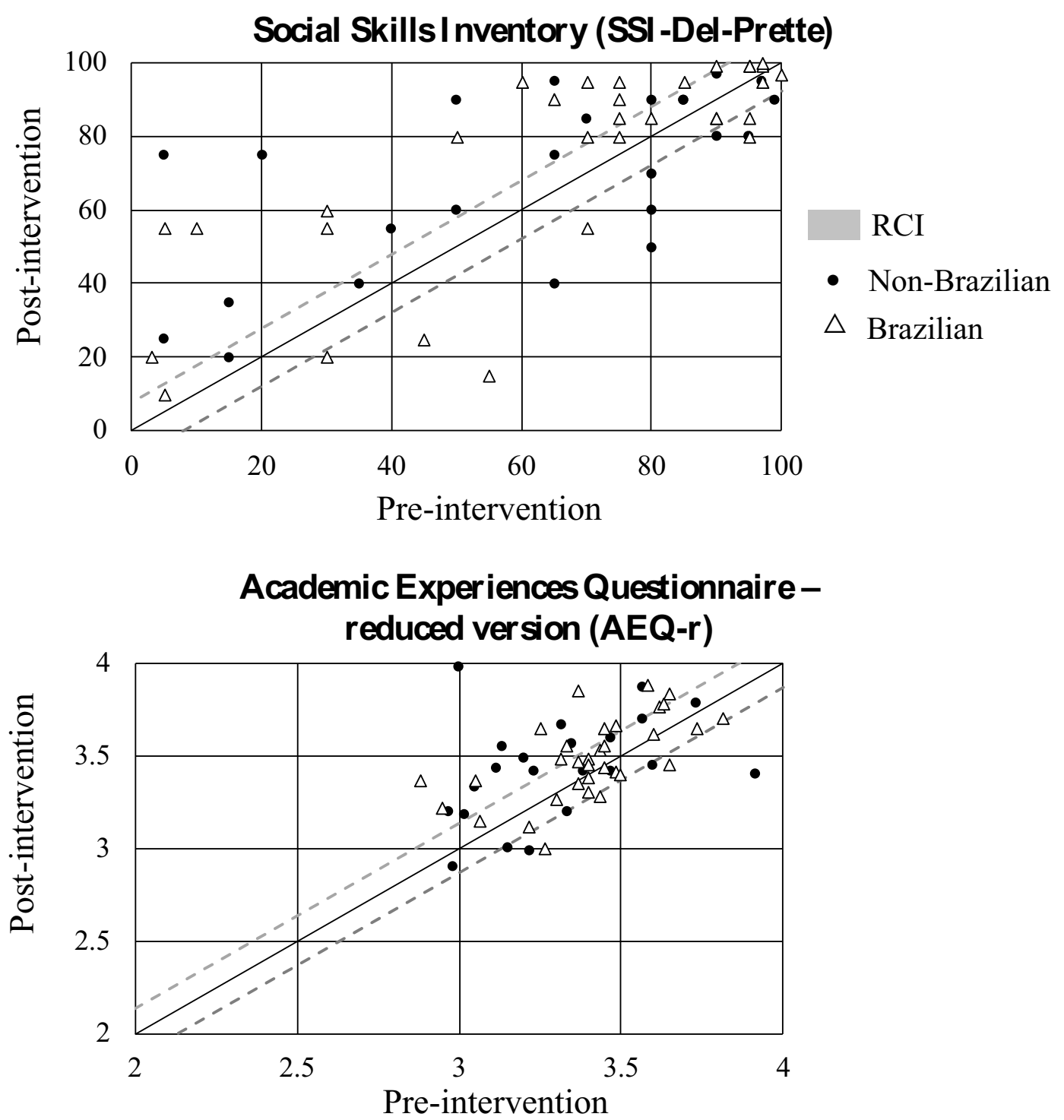

Figure 1. Scatter Plot of Pre- and Post- Intervention on the AEQ-r and SSI-DEL-Prette with Jagged Band Showing RCI.

\section{Discussion}

The outcomes show that seven sessions of psychoeducational intervention could improve several skills related to communication, such as conversation, social and interpersonal skills for incoming medical students in academic settings. All skills developed during this intervention would be important requirements for the development of further competences in academic and professional settings, which will be analyzed in a long-term follow up study. The development of social, interpersonal and academic skills is deeply associated with emotional intelligence (Johnson, 2015; Satterfield \& Hughes, 2007). Lately, these skills have been increasingly required for medical undergraduate students in different areas. As described above, a person 
with high scores in both social and academic competences will present better outcomes related to quality of life, personal satisfaction, professional accomplishment, and interpersonal relationships than a person with little or no competences in such areas. Similar outcomes have been found beneficial with college students in different phases of their undergraduate course (Malinauskas, Dumciene, \& Lapeniene, 2014; Pureza et al., 2012). Besides a low quality of life, deficits in communication and social skills have been described in several studies as an important variable in the development of mental disorders (Benbassat \& Baumal, 2005; Gysels et al., 2004; Wagner et al., 2002).

Highly significant differences in assertiveness and the ability to cope in situations with risk was observed. The SSI-Del-Prette assessed situations, such as introducing oneself to an unknown person, disagreeing with authority or colleagues in a group, requesting the payment of debt from friend, dealing with unfair criticism, returning defective product to a store, and asking questions to acquaintances (Del-Prette \& Del-Prette, 2016). All these skills were directly addressed through training in the psychoeducational intervention during specific sessions focused on communications and interpersonal patterns (e.g., assertive, aggressive and passive), feedback and conflicts. The relevant positive results in post intervention scores could be attributed to the intervention training developed around that group of skills. Similar results were found in interventions focused on assertiveness and the ability to cope with different populations as described by some authors (e.g., Lin et al., 2004).

Significant difference in conversation, communication and social interaction without risk were also found. According to SSI-DelPrette, situations assessed pre- and postpsychoeducational intervention should involve keeping up and ending conversation during faceto-face contact, approaching people in positions of authority, asking a favor from colleagues, and rejecting abusive requests (Del-Prette \& DelPrette, 2016). Content and learning strategies adopted during the intervention focused directly and indirectly on this group of communication skills. During our sessions, the main strategies adopted were role-play and rehearsal of simulated physician-patient situations, pair conversations and activities in teams and groups. All activities increased the probability of conversation, social and interpersonal interactions, and consequently the likelihood of developing social and interpersonal skills. Similar results were found in studies focused on communication and social interaction during a specific period or, in some cases, the whole undergraduate course (Choudhary \& Gupta, 2015; Levinson, Lesser, \& Epstein, 2010; Modi, Chhatwal, Gupta, \& Singh, 2016; Stepien \& Baernstein, 2006; Yedidia \& Gillespie, 2003).

Some studies demonstrated the importance of the development of communication and interpersonal skills as a way to prevent the erosion of empathy of medical students during their whole undergraduate course or professional life (Benbassat \& Baumal, 2005; Gysels et al., 2004; Wagner et al., 2002). According to Grewal (2008), communication is deeply related to empathy because a successful communication involves a complex process of perceiving emotions, managing one's own reactions, and using emotion to facilitate performance (e.g., relationships between physician-patient or physician and other professionals). Additionally, interventions focused on communication and, in some cases, in interpersonal skills could be a good option to integrate and decrease the effects of cultural impacts of a new university and/ or country for international incoming students (Tavakoli et al., 2009). Group interventions focused on social and interpersonal skills may be more acceptable than individual interventions with the same targets.

Similar results related to social and interpersonal in SSI-Del-Prette skills were found in the interpersonal domain of AEQ-r. This intervention found a highly significant difference between pre- and post-evaluation in the interpersonal domain of AEQ-r as well as in the SSI-Del-Prette total score. However, there were no significant differences in the domains related to personal or learning issues. 
One possible explanation for these results was the content and the focus of the present study: all sessions were focused on the development of social, interpersonal and communications skills and the aim was not to develop personal characteristics and skills, such as emotional balance, self-confidence and problem solving. These skills are important and need to be developed during the whole undergraduate medical course and could be the focus and aim of further studies (e.g., long-term follow up study). Interventions focused on learning strategies, such as time management or study habits, and personal characteristics are important due to the role of emotional intelligence for academic and personal life (Grewal, 2008; Johnson, 2015).

Other groups of skills assessed during our study were self-assertion in the expression of positive contents, self-exposure to unknown people and new situations, and self-control of aggressiveness. As for the personal domain of AEQ-r, there were no significant differences between pre- and post-intervention. Here again, the possible explanation for the results in selfexposure to unknown people and new situations was not the main aim of this intervention and the results could be explained in two ways: (a) the students had already developed theses skills prior to the intervention in other situations and contexts or (b) the students developed theses skills during their reception at the university due to the necessity of integration to new persons and, in the case of international incoming students, to a new country and culture. Self-assertion in the expression of positive contents and self-control of aggressiveness had no differences between pre- and post-intervention. As described above regarding self-assertion in the expression, and self-exposure to unknown people and new situations, this set of skills was not targeted during training in the present study.

For two domains in AEQ-r, career and institution, we found significant differences between pre- and post-psychoeducational intervention. One possible reason for that was the new knowledge that the medical students had about the institution (e.g., main characteristics of this particular, medical school, the lecturers and fellows) and medical careers (e.g., knowledge about competences and skills required from the students) at the end of the first academic term when compared to the first week of the undergraduate medical school. As described, this is a bilingual university which has special characteristics in comparison with other public or private medical schools in Brazil or Latin America. Besides these characteristics, one additional explanation is the transition and difficulties between high school and college (Igue, Bariani, \& Milanesi, 2008). In the first class (and right before intervention) students were described what to expect from college life. According to Cunha and Carrillo (2005), and Nogueira (2017), expectations and academic experiences with academic institution, assessed by the institutional domain, could be deeply related with the development of social and interpersonal skills, quality of life and academic outcomes of students.

The original hypotheses were that cultural and linguistic differences between students could negatively affect the final results at the end of the first academic term. According to Tavakoli et al. (2009) and Terrazas-Carrillo et al (2014), international incoming students have an additional challenge when compared to national/ home students: they need to adapt to an undergraduate life and to develop bicultural competences or second culture acquisition. Although the main results demonstrated that kind of difference was not important during an intervention focused on social and interpersonal skills, the results related to these skills in the present study were statistically significant.

The focus of this study was not to evaluate and to compare medical students from different countries but analyze the results after a short-term intervention with specific scales and methods. The reasons why we did not try to compare students from different countries were: (a) the large difference between the number of students of different countries (e.g., Brazil had with 33 students and Guatemala had only one) and (b) all foreign students were from different countries and regions of Latin America with significant 
differences in culture, habits and behavior. The large difference between countries does not enable us to group the students from other countries in a single group and then to compare with all Brazilian students. Moreover, the present study faced additional limitations, such as the absence of a control group to compare the results of the present psychoeducational intervention with, a convenience sample as well as the use of self-report questionnaires and scales.

In conclusion, short-term intervention could improve the development of several skills related to communication, such as conversation, social and interpersonal skills. This study demonstrated the importance of early interventions for the development of these skills for undergraduate medical students in all settings, such as breaking bad news, empathy, counseling, and communication with patients, and to prevent the erosion of empathy and interpersonal relationships. Apparently, the cultural and linguistic differences did not influence the results of our intervention. In this way, further studies focused on the development of social, interpersonal and communication skills prior to undergraduate medical school are suggested as well as a longitudinal study to assess the development and changes in these skills during the whole undergraduate medical course. Additionally, the influence of nationality and culture in the development of social, interpersonal and communication skills could be the focus of further studies with undergraduate students of any area.

\section{Acknowledgment}

Simone Appenzeller received financial support CNPq (304255/2015-7) e Coordenação de Aperfeiçoamento de Pessoal de Nível Superior - Brasil (CAPES) - financing code 001.

\section{References}

Al Odhayani, A., \& Ratnapalan, S. (2011). Teaching communication skills. Canadian Family Physician Medecin de Famille Canadien, 57(10), 1216-1218. Retrieved from http://www. ncbi.nlm.nih.gov/pubmed/21998240
Argyle, M., Furnham, A., \& Graham, J. A. (1980). Social Situations. Cambridge, MA: Cambridge University Press.

Benbassat, J., \& Baumal, R. (2005). Enhancing selfawareness in medical students: An overview of teaching approaches. Academic Medicine: Journal of the Association of American Medical Colleges, 80(2), 156-161. Retrieved from https:/journals.lww.com/academicmedicine/ Fulltext/2005/02000/Enhancing_Self_ Awareness_in_Medical_Students_An.10.aspx

Biggs, J. S. G., Agger, S. K., Dent, T. H. S., Allery, L. A., \& Coles, C. (1994). Training for medical teachers: A UK survey, 1993. Medical Education, 28(2), 99-106. https://doi. org/10.1111/j.1365-2923.1994.tb02527.x

Caballo, V. E. (2007). Manual de evaluación y entrenamiento de las habilidades sociales (7th Ed.). Madrid: Siglo XXI de España.

Choudhary, A., \& Gupta, V. (2015). Teaching communications skills to medical students: Introducing the fine art of medical practice. International Journal of Applied and Basic Medical Research, 5(4, Suppl. 1), S41-S44. https://doi.org/10.4103/2229-516X.162273

Cunha, S. M., \& Carrilho, D. M. (2005). O processo de adaptação ao ensino superior e o rendimento acadêmico. Psicologia Escolar e Educacional, 9(2), 215-224. https://doi.org/10.1590/S141385572005000200004

Del Prette, Z. A. P., \& Del Prette, A. (2013). Social Skills Inventory (SSI-Del-Prette): Characteristics and studies in Brazil. In F. L. Osório (Ed.), Social anxiety disorders: From research to practice (pp. 49-62). New York: Nova Science.

Del-Prette, Z. A. P., \& Del-Prette, A. (2016). Inventário de Habilidades Sociais: Manual de Aplicação, Apuração e Interpretação (6th Ed.). São Paulo, SP: Casa do Psicólogo.

Denniston, C., Molloy, E., Nestel, D., WoodwardKron, R., \& Keating, J. L. (2017). Learning outcomes for communication skills across the health professions: A systematic literature review and qualitative synthesis. BMJ Open, 7(4), e014570. http://dx.doi.org/10.1136/ bmjopen-2016-014570

Deveugele, M. (2015). Communication training: Skills and beyond. Patient Education and 
Counseling, 98(10), 1287-1291. https://doi. org/10.1016/j.pec.2015.08.011

Granado, J. I. F., Santos, A. A. A., Almeida, L. S., Soares, A. P., \& Guisande, M. A. (2005). Integração académica de estudantes universitários: Contributos para a adaptação e validação do QVA-r no Brasil. Psicologia e Educação, 4(2), 31-41. Retrieved from http://repositorium.sdum.uminho.pt/ handle/1822/12089

Grewal, D. (2008). Emotional intelligence and graduate medical education. JAMA, 300(10), 1200-1202. http://dx.doi.org/10.1001/ jama.300.10.1200

Gysels, M., Richardson, A., \& Higginson, I. J. (2004). Communication training for health professionals who care for patients with cancer: A systematic review of effectiveness. Supportive Care in Cancer, 12(10), 692-700.

IBM Corp. (2015). IBM SPSS Statistics (Version 23) [Computer software]. Armonk, NY: Author.

Igue, É. A., Bariani, I. C. D., \& Milanesi, P. V. B. (2008). Vivência acadêmica e expectativas de universitários ingressantes e concluintes. PsicoUSF, 13(2), 155-164. http://dx.doi. org/10.1590/S1413-82712008000200003

Jacobson, N. S., \& Truax, P. (1991). Clinical significance: A statistical approach to defining meaningful change in psychotherapy research. Journal of Consulting and Clinical Psychology, 59(1), 12-19. http://dx.doi.org/10.1037/0022006X.59.1.12

Johnson, D. R. (2015). Emotional intelligence as a crucial component to medical education. International Journal of Medical Education, 6, 179-183. http://dx.doi.org/10.5116/ ijme.5654.3044

Levinson, W., Lesser, C. S., \& Epstein, R. M. (2010). Developing physician communication skills for patient-centered care. Health Affairs, 29(7), 1310-1318. http://dx.doi.org/10.1377/ hlthaff.2009.0450

Lin, Y.-R., Shiah, I.-S., Chang, Y.-C., Lai, T.-J., Wang, K.-Y., \& Chou, K.-R. (2004). Evaluation of an assertiveness training program on nursing and medical students' assertiveness, self-esteem, and interpersonal communication satisfaction. Nurse Education Today, 24(8), 656-665. http:// dx.doi.org/10.1016/j.nedt.2004.09.004
Malinauskas, R., Dumciene, A., \& Lapeniene, D. (2014). Social skills and life satisfaction of Lithuanian first- and senior-year university students. Social Behavior and Personality: An International Journal, 42(2), 285-293. http:// dx.doi.org/10.2224/sbp.2014.42.2.285

McCallin, A., \& Bamford, A. (2007). Interdisciplinary teamwork: Is the influence of emotional intelligence fully appreciated? Journal of Nursing Management, 15(4), 386-391. https:// doi.org/10.1111/j.1365-2834.2007.00711.x

Mesidor, J. K., \& Sly, K. F. (2016). Factors that contribute to the adjustment of international students. Journal of International Students, 6(1), 262-282. Retrieved from https://eric. ed.gov/?id=EJ1083269

Modi, J. N., Chhatwal, J., Gupta, P., \& Singh, T. (2016). Teaching and assessing communication skills in medical undergraduate training. Indian Pediatrics, 53(6), 497-504. Retrieved from https://www.indianpediatrics.net/june2016/497. pdf

Nogueira, M. J.C. (2017). Saúde mental em estudantes do ensino superior: Fatores protetores e fatores de vulnerabilidade (Unpublished doctoral thesis, Universidade de Lisboa, Portugal).

Olaz, F. O., Medrano, L., Greco, M. E., \& Del Prette, Z. A. P. (2009). Argentinean adaptation of the Social Skills Inventory IHS-Del-Prette. The Spanish Journal of Psychology, 12(2), 756-766.

Pascarella, E. T., \& Terenzini, P. (1991). How college affects students: Findings and insights from twenty years of research. San Francisco, CA: JosseyBass.

Pureza, J. D. R., Rusch, S. G. D. S., Wagner, M., \& Oliveira, M. D. S. (2012). Social Skills Training for College Students: A intervention proposal. Revista Brasileira de Terapias Cognitivas, $8(1)$, 2-9. https://doi.org/10.5935/18085687.20120002

Rodríguez, D. P. M., Urazán, S. C. O., \& Arango, M. I. R. (2009). Cuestionario de Vivencias Académicas en su versión reducida (QVA-r): un análisis psicométrico. Revista Colombiana de Psicología, 18(1), 33-52. Retrieved from https:// revistas.unal.edu.co/index.php/psicologia/ article/view/1450/36208

Satterfield, J. M., \& Hughes, E. (2007). Emotion skills training for medical students: A systematic review. Medical Education, 41(10), 
935-941. http://dx.doi.org/10.1111/j.13652923.2007.02835.x

Sorinola, O. (2014). A realist evaluation of faculty development in UK medical schools (Doctoral dissertation, University of Warwick, UK).

Stepien, K. A., \& Baernstein, A. (2006). Educating for empathy. Journal of General Internal Medicine, 21(5), 524-530. https://doi.org/10.1111/j.15251497.2006.00443.x

Tavakoli, S., Lumley, M. A., Hijazi, A. M., SlavinSpenny, O. M., \& Parris, G. P. (2009). Effects of assertiveness training and expressive writing on acculturative stress in international students: A randomized trial. Journal of Counseling Psychology, 56(4), 590-596. http://dx.doi. org/10.1037/a0016634

Terrazas-Carrillo, E. C., Hong, J. Y., \& Pace, T. M. (2014). Adjusting to new places: International student adjustment and place attachment. Journal of College Student Development, 55(7), 693-706. https://doi.org/10.1353/csd.2014.0070
Wagner, P. J., Moseley, G. C., Grant, M. M., Gore, J. R., \& Owens, C. (2002). Physicians' emotional intelligence and patient satisfaction. Family Medicine, 34(10), 750-754.

Yedidia, M., \& Gillespie, C. (2003). Effect of communications training on medical student performance. JAMA, 290(9), 1157-1165. https:// doi.org/10.1001/jama.290.9.1157

Zick, A., Granieri, M., \& Makoul, G. (2007). Firstyear medical students' assessment of their own communication skills: A video-based, open-ended approach. Patient Education and Counseling, 68(2), 161-166. https://doi. org/10.1016/j.pec.2007.05.018 